\title{
Laparoscopic Three-Port Sleeve Gastrectomy: Description of the Technique and Preliminary Results
}

\author{
HOSAM B. BARAKAT, M.D.; ALHASSAN M. HASSAN, M.D.; SHERIF M. ELGARF, M.D.; \\ GAMAL I. MOUSSA, M.D. and TAMER M. ELMAHDY, M.D.
}

The Department of General Surgery, Faculty of Medicine, Tanta University

\begin{abstract}
Background: Up till now, there is no standardized technique for performing Laparoscopic sleeve gastrectomy (LSG).

Aim of Study: The aim of this study was to assess the feasibility of LSG by means of three port technique and reporting short term results.

Patients and Methods: This was a prospective study done from February to December 2019. Twenty-eight morbidly obese patients (18 females and 10 males) were included. Mean age of $31.03 \pm 8.89$ years, mean preoperative body mass index of $44.38 \pm 5.32 \mathrm{~kg} / \mathrm{m}^{2}$. This study discussed the patients' demographics, operative technique, operative records, post-operative outcomes concerning excess weight loss, comorbidities resolution, complication rates, pain assessment and patients' scars satisfaction. Follow-up was done at 10 day, 1, 3, 6, and 12 months.
\end{abstract}

Results: All procedures were completed laparoscopically. Mean operative time was $58.46 \pm 18.61$ minutes. The mean hospital stay was $1.25 \pm 0.75$ day. The $\% E W L$ was $23.91 \%$, $40.22 \%, 55.69 \%$, and $69.65 \%$ at $1,3,6$, and 12 months, respectively. Within a 6 to 12 month postoperatively, $50 \%$ of patients with hypertension (HTN) presented with significant improvement, all diabetic patients described resolution or significant improvement and $62.5 \%$ of patients with arthralgia had improved.

Conclusions: Three ports LSG is feasible without need for liver retractor port insertion, safe, effective, with short hospital stay and good cosmetic results.

Key Words: Laparoscopic sleeve - Three port - Weight loss.

\section{Introduction}

THE standard LSG procedure described by Gagner requires more than five port placements in the upper abdomen [1]. The main principle behind every new emerging technique has been reduction of pain, achieving better esthetic results and reduction in the hospital stay whilst having comparable

Correspondence to: Dr. Hosam B. Barakat,

E-Mail: elbohotyhossam2018@gmail.com results and morbidity rates as the conventionally accepted procedures [2]. During the past few years, different LSG techniques have been emerged focusing on lesser invasive surgical procedures [3]. Single-incision laparoscopic sleeve gastrectomy (SILSG) is one of these techniques that has an accepted postoperative results as regard weight loss and wound complications [4]. The main disadvantages of single incision approach are technical difficulties, complex instruments and loss of triangulation because of the limited area of movement [3]. LSG by means of three-port technique has been described by some bariatric surgeons as a promising alternative between the standard LSG and SILS (SILS-SG) [5].

\section{Patients and Methods}

This was a prospective study, done from February to December 2019 on 28 morbid obese patients. Inclusion criteria were chronic morbid obesity (BMI $>40$ or BMI $\geq 35 \mathrm{~kg} / \mathrm{m}^{2}$ with comorbidities), with failure of conservative treatment. Exclusion criteria were: Pregnancy, uncontrolled drug or alcohol dependency, previous upper abdominal or bariatric procedures, patients with psychiatric impairment, and patients with evident clinical reflux. Written informed consent was obtained from all the patients who are included in this study.

\footnotetext{
Abbreviations:

LSG : Laparoscopic sleeve

BMI : Body mass index

EWL : Excess weight loss

GERD : Gastro-esophageal reflux disease

SILSG : Single-incision laparoscopic sleeve gastrectomy

T2DM : Type 2 diabetes mellitus

HTN : Hypertension

VAS : Visual analogue scale

PSAQ : Patient scar assessment questionnaire.
} 
The study protocol was approved by the Institutional Ethical Committee. All the operations were performed by the same surgeons (the authors). This study discussed the technique of the procedure, patients' demographic details, postoperative convalescence, excess weight loss percentage (\%EWL), resolution of comorbidities, early and late complications, postoperative pain score (Visual analogue scales) and patient's scars satisfaction. Assessment of patient's scar satisfaction was accomplished by using patient scar assessment questionnaire (PSAQ) [6] and by asking every patient to grade his or her overall satisfaction with scar appearance as very satisfied, satisfied, dissatisfied, or very dissatisfied. The PSAQ consists of four validated subscales which are: Appearance, consciousness, satisfaction with appearance, and satisfaction with symptoms; each subscale consists of a set of items with fourpoint categorical responses, ranging from 1 (most favorable) to 4 (least favorable).

\section{Statistical analysis:}

Data were collected and analyzed using SPSS software package version, 20 (SPSS Inc., Chicago, Illinois, USA). Categorical data were expressed as number and frequency (percentage). Metric data were reported as range, mean, and Standard Deviation.

\section{Preoperative considerations:}

All cases were subjected to routine investigations, hormonal assay (specifically serum TSH and cortisol levels) to exclude secondary causes of obesity and abdominal ultrasonography to detect patients with gallbladder stones and to measure liver span. All patients were put on a strict highprotein, low-fat, and low carbohydrate diet for 46 weeks with a minimum of two weeks prior to surgery. Initiation of this low-calorie diet prior to surgery helps to shrink the large fatty liver and thus minimizing need for liver retractor port insertion. All patients received enoxaparin (Clexane) 40 IU night of the procedure.

\section{Surgical technique:}

General anesthesia was given. The patients were placed in the supine split-leg position (French position) and reverse Trendelenburg. Sequential compression stocking was placed for DVT prophylaxis. The endoscopic set was positioned at the head of the patient on the left side. The surgeon stands in-between patient's legs and the camera man stands on the patient's right. Three trocars were used, Fig. (1). The first $12 \mathrm{~mm} \mathrm{~mm}$ ENDOPATH XCEL port was inserted within the umbilicus at its upper border for the $30^{\circ}$ optical system; the second $12 \mathrm{~mm}$ trocar inserted $5-7 \mathrm{~cm}$ below the left costal margin on the midclavicular line (surgeon right hand); and the third $5 \mathrm{~mm}$ trocar inserted at lateral border of the right rectus nearly at same level of the left $12 \mathrm{~mm}$ port (surgeon left hand). Entering the abdominal cavity is done under direct vision using visiport technique, pneumoperitoneum is created (pressure of $14-16 \mathrm{mmHg}$ ), devascularization of the greater curvature of the stomach was initiated at its half way using harmonic scalpel introduced through left $12 \mathrm{~mm}$ trocar aided by upward elevation of the gastric wall using a traumatic grasper Fig. (2). Dissection was continued cephalic up to left crus of diaphragm, where left hand of surgeon elevated the gastric wall anteriorly in a vertical manner allowing elevation of left lobe of the liver at the same time, Fig. (3). The posterior aspect of the fundus of the stomach was dissected completely exposing left crus of diaphragm, Fig. (4). Dissection was then continued caudally toward the pylorus ending the dissection $2 \mathrm{~cm}$ proximal to the pylorus. The LSG was performed by sequentially firing an articulating linear stapler (Echelon Flex ${ }^{\mathrm{TM}}$ Endopath, Ethicon Endo-surgery Inc., Johnson and Johnson, Cincinnati, OH, United States), close to a 36-fr orogastric tube. The gastric stapling started at $5 \mathrm{~cm}$ proximal to the pylorus through the midline $12 \mathrm{~mm}$ port while transporting the $30^{\circ}$ angle scope through left $12 \mathrm{~mm}$ port, Fig. (5). The first stapling was done using a $60 \mathrm{~mm}$ green staple cartridge $(4.1 \mathrm{~mm})$ with great attention not to narrow the sleeve at the incisura angularis by keeping the stapler just at the end of the gastric wall vessels, cartridge $(3.8 \mathrm{~mm})$ and average 3-4 blue loads $(3.6 \mathrm{~mm})$ till complete gastric division being close to the calibration tube without any traction on the gastric wall, Fig. (8). The first stapling was the easiest one as the distal stomach not covered by the liver, however, the difficulty appeared on subsequent stapling. We overcome this by elevating the left lobe of the liver by left surgeon hand while sliding the stapler gradually through the angle of the divided stomach without exerting any sort of traction on lateral gastric wall. We routinely do not oversew or use any type of reinforcing material over the staple line. Hemostasis of the staple line bleeding points was achieved by application of surgical clips and if failed, we oversew the staple line just at bleeding points. Methylene blue test was done routinely to exclude leak. The gastric specimen was extracted through the left $12 \mathrm{~mm}$ port site, Fig. (9). A tube drain was applied routinely intra-abdominally in subsplenic area through site of left port, Fig. (10). We did not close the sheath at any of trocar sites. 


\section{Post-operative:}

All patients received oral clear fluid small snips $8 \mathrm{~h}$ post operatively, very soft solid food as yoghurt $16 \mathrm{~h}$ post operatively. Drain removal and discharge of non-complicated cases in the second

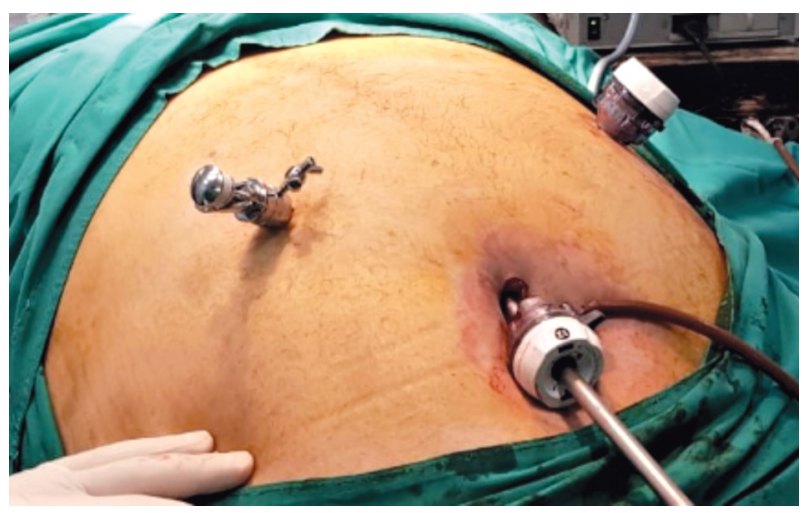

Fig. (1): Three ports positions.

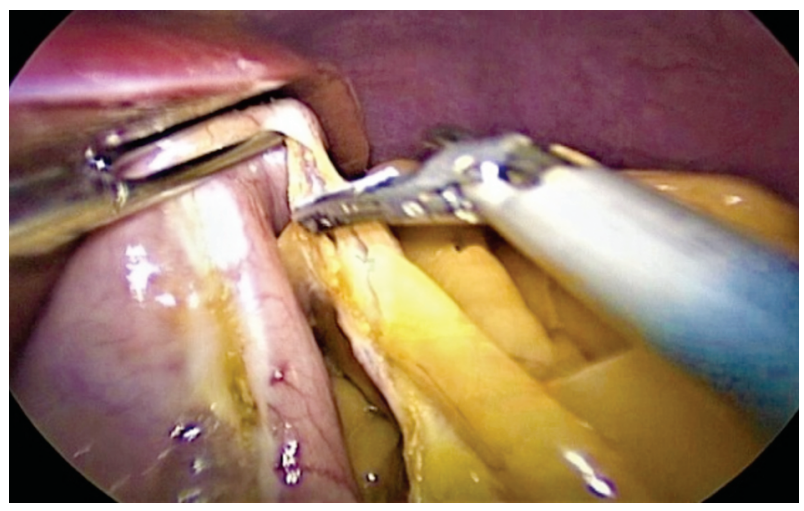

Fig. (3): Liver elevation by left surgeon's hand.

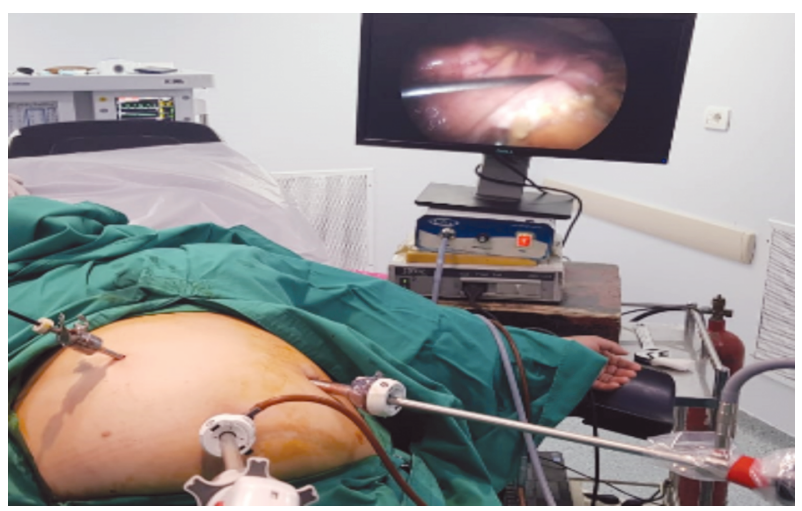

Fig. (5): The stapler introduced through the umblical port. postoperative day. Low molecular weight heparin, prophylactic dose was given every 24 hours up to 2 weeks post-operative. Gastric protection with proton pump inhibitors for the first two months postoperatively.

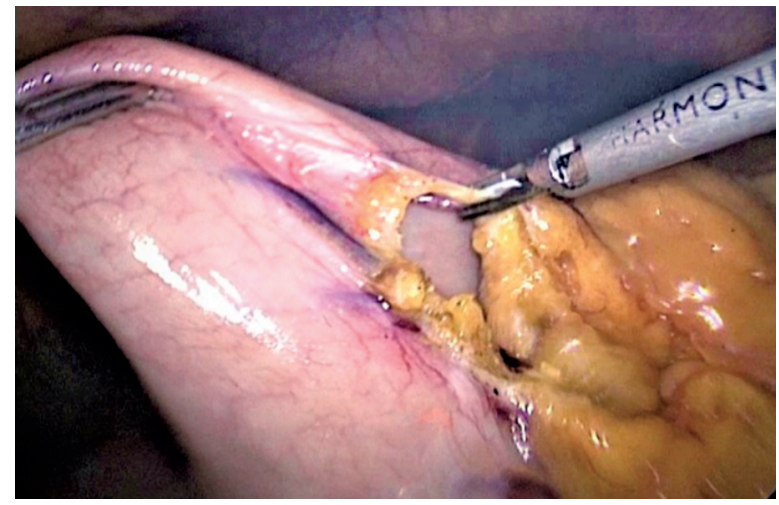

Fig. (2): Initiation of greater curvature mobilization at its half way.

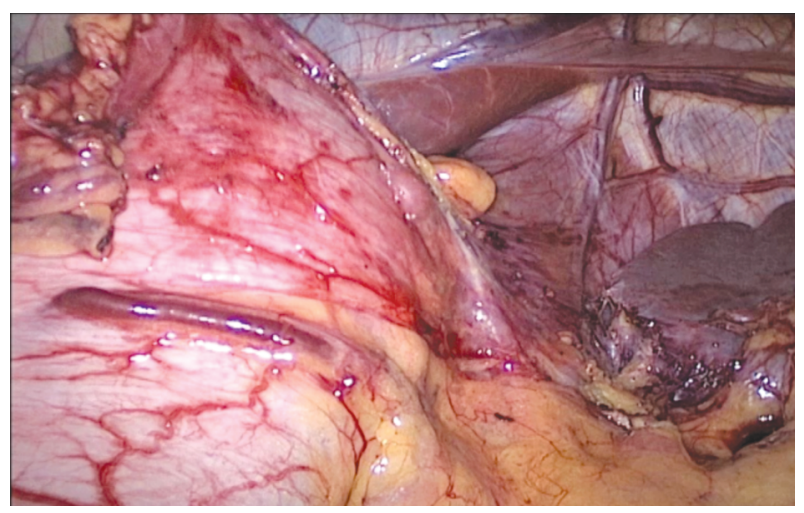

Fig. (4): Complete fundal mobilization during cranial mobilization.

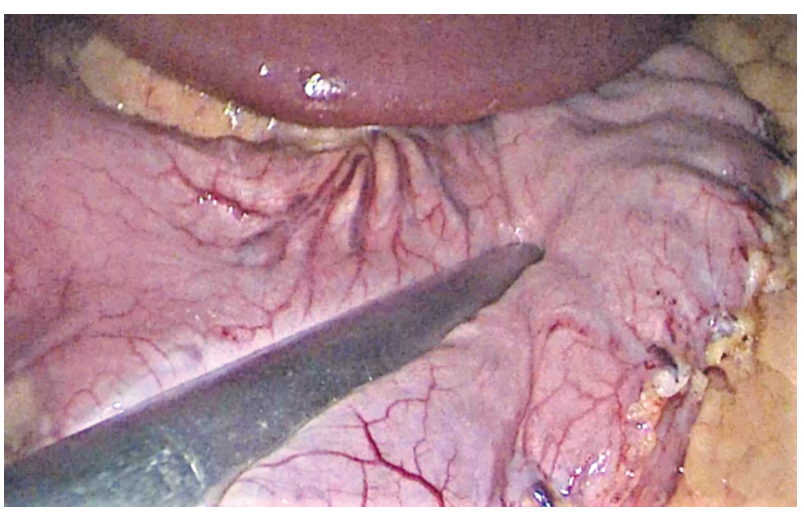

Fig. (6): The stapler applied just at the end of gastric wall vessels at the incisura. 


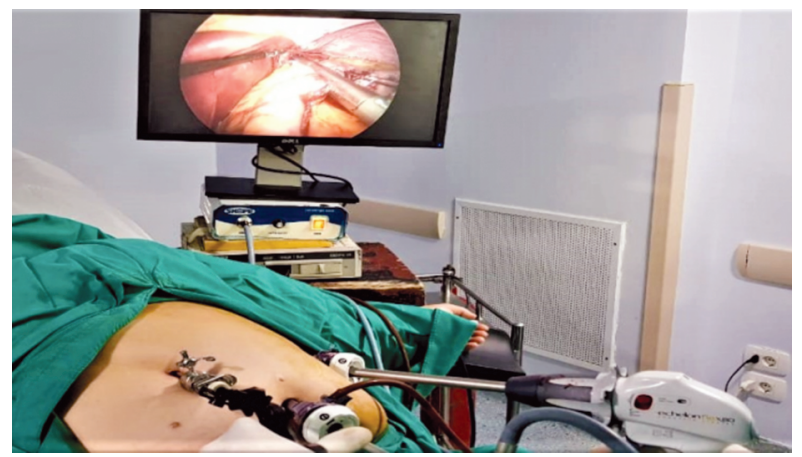

Fig. (7): Sequential firing was done through left port.

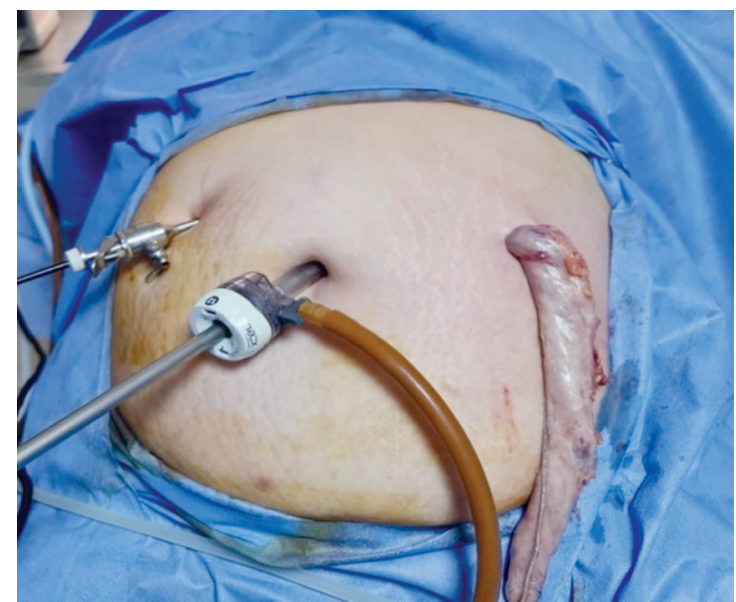

Fig. (9): Speicmen extraction through site of left port.

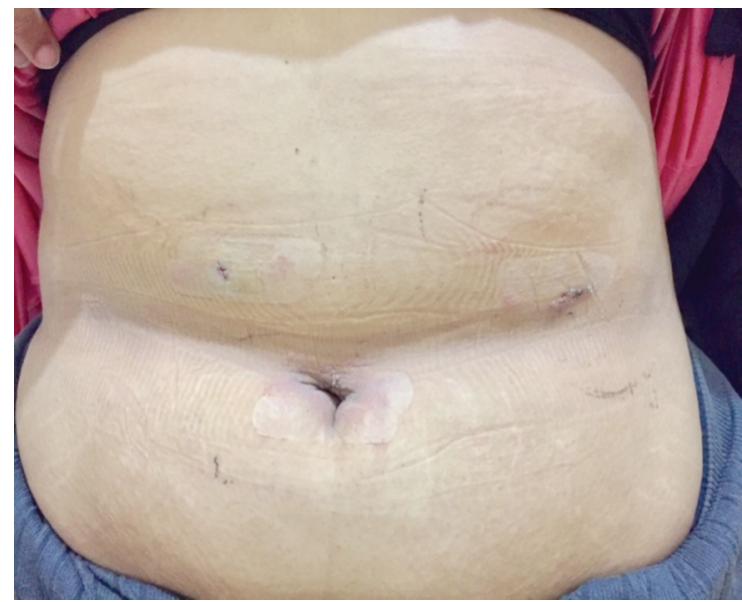

Fig. (11): Scars 10 days post-operative.

\section{Results}

This prospective study included 28 morbidly obese patients. The demographic characteristics demonstrated in Table (1).

\section{Operative records and hospital stay:}

The mean operative time was $58.46 \pm 18.61$ minutes, ranged between (30-100) minutes. An Additional port was necessary in three patients.

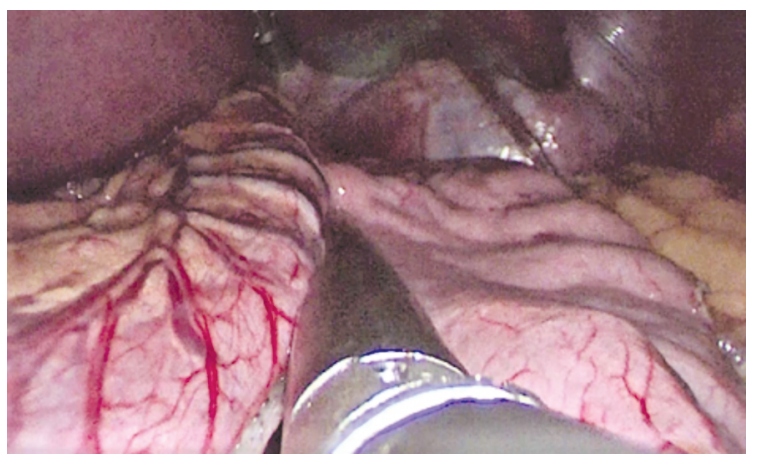

Fig. (8): Sequential firing close to calibration tube.

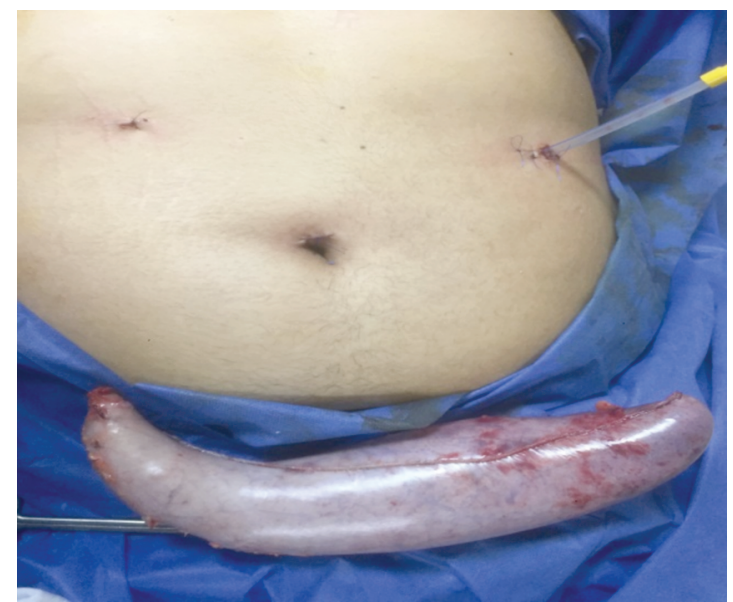

Fig. (10): A tube drain was applied routinely though left port site.

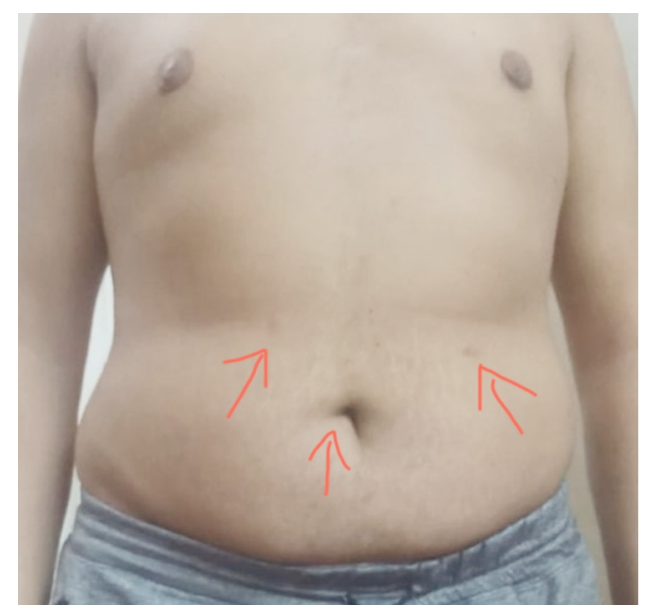

Fig. (12): Scars 6 month post-operative.

Two of them required one $5 \mathrm{~mm}$ epigastric port to retract liver to aid in haemostasis. The third patient required $5 \mathrm{~mm}$ port to aid in concomitant cholecystectomy. The mean length of hospital stay was $1.28 \pm 0.76$ day (range, $1-4$ day).

\section{Morbidity and mortality:}

There was no mortality or conversion to open surgery. The total $30 \mathrm{~d}$ postoperative complication rate was $10.7 \%$ (3/28 patients). One patient (3.5\%) 
had early post-operative bleeding within first $24 \mathrm{~h}$ post-operative however, managed conservatively with no harmful sequence and discharged $4^{\text {th }}$ day postoperative. Two patients developed repeated vomiting and intolerance to oral fluid and were managed conservatively by intravenous fluid therapy and antiemetic drugs with gradual improvement. Regarding late complications, two patients (7.1\%) developed symptoms suggesting gastroesophageal reflux 3 to 6 month postoperative and both improved on daily low-dose of PPI, cholecystectomy due to symptomatic gallstones was performed during the follow-up in 1 patient $(3.5 \%)$.

\section{Weight loss:}

Mean EWL\% was $23.9 \%$ at 1 month, $40.2 \%$ at 3 months, $55.96 \%$ at 6 months, and $69.6 \%$ at 12 months (Table 1). All patients lost weight during the first year, however, one patients lost weight but not efficiently (EW loss \% less than $50 \%$ at one year).

\section{Resolution of co-morbidities:}

After the first post-operative year, most of the co-morbidities improved or resolved. Resolution /improvement of co-morbidities were $100 \%$ for diabetes mellitus, $50 \%$ for hypertension, and $62.5 \%$ for degenerated joint disease.

\section{Patients scars satisfaction:}

Assessment of patient's satisfaction regarding the abdominal wall scars at sites of trocars using PSAQ at 1, 3, and 6 months post-operative revealed a mean of $42.23 \pm 7.35,34.12 \pm 4.49,30 \pm 2.76$ respectively (Table 1). The best results were achieved at 6 month. As regard the overall satisfaction with the scar appearance, 20 patients were very satisfied while the rest were just satisfied with the scar appearance.

Table (1): Patients' scar assessment questionnaire results $(\mathrm{N}=28)$.

\begin{tabular}{lcccccc}
\hline Subscales & $\begin{array}{c}\text { N of } \\
\text { Scored Items }\end{array}$ & $\begin{array}{c}\text { Min } \\
\text { score }\end{array}$ & $\begin{array}{l}\text { Max } \\
\text { score }\end{array}$ & 1 month & 3 month & 6 month \\
\hline Appearance & 9 & 9 & 36 & $13.89 \pm 2.26$ & $10.96 \pm 1.45$ & $9.53 \pm 0.63$ \\
Consciousness & 6 & 6 & 24 & $7.46 \pm 1.2$ & $6.64 \pm .91$ & $6.28 \pm .65$ \\
Satisfaction with appearance & 8 & 8 & 32 & $13.78 \pm 2.61$ & $10.17 \pm 1.15$ & $9 \pm 0.8$ \\
Satisfaction with symptoms & 5 & 5 & 20 & $7.10 \pm 1.28$ & $6.35 \pm .98$ & $5.5 \pm .68$ \\
\hline Total & 28 & 28 & 112 & $42.23 \pm 7.35$ & $34.12 \pm 4.49$ & $30 \pm 2.76$ \\
\hline
\end{tabular}

Min: Minimum. Max: Maximum. N: Number.

Table (2): Patients' demographic characteristics.

\begin{tabular}{|c|c|}
\hline Gender: Female/Male & $18 / 10$ \\
\hline Age: Mean \pm SD (Rang) & $\begin{array}{l}31.03 \pm 8.89 \\
\text { (rang 20-55) }\end{array}$ \\
\hline $\begin{array}{l}\text { Pre-operative weight: } \\
\text { Mean } \pm \text { SD (Rang) }\end{array}$ & $\begin{array}{l}122 \pm 21.57 \\
(90-180)\end{array}$ \\
\hline $\begin{array}{l}\text { Pre-operative BMI: } \\
\text { Mean } \pm \text { SD (Rang) }\end{array}$ & $\begin{array}{l}44.38 \pm 5.32 \\
\left(37.3 \text { to } 55.5 \mathrm{~kg} / \mathrm{m}^{2}\right)\end{array}$ \\
\hline \multicolumn{2}{|l|}{ Obesity related co-morbidities: } \\
\hline Diabetes N, (percentage) & $3(10.7 \%)$ \\
\hline Hypertension N, (percentage) & $2(7.1 \%)$ \\
\hline Chronic joint pain $\mathrm{N}$, (percentage) & $8(28.5 \%)$ \\
\hline Cholelithiasis & $2(7.1 \%)$ \\
\hline
\end{tabular}

N: Number. SD: Standard deviation.

\section{Discussion}

Several reasons, besides the good result of weight loss, have contributed to the world wide acceptance of LSG. It is considered operation technically easier, shorter operative time, maintenance of bowel integrity and preservation of the pylorus [7,8]. Although LSG is currently considered the gold standard procedure for a large number of bariatric surgeons, many controversies of the technique still present. Some of these controversies are, the distance from the pylorus, the routine use of intraoperative seal testing, the size of the orogastric calibration tube, reinforcement of the staple line, and the considerations in case of revision LSG requirement [9]. The only consensual aspect is that the sleeve gastrectomy should be done by laparoscopy because laparoscopy facilitates safe dissection of the greater curvature near the spleen by direct vision thus decreasing probability of iatrogenic injury [10]. Starting in 2013, more than 500 morbid obese patients underwent LSG by means of four port technique in our department. The objective of this study was to report our experience and short term results of LSG using only three ports technique. When compared to conventional LSG, three port technique miss both the assistant and liver retractor port. In addition, the entire surgery is performed without any counter traction. Long-length of scope and instruments were mandatory in our technique especially in tall 
patients due to relative low insertion of trocars. Increasing intra-abdominal fat content and large fatty livers representing the main difficulty in application of this technique. Our preoperative nutritional protocol in LSG entails providing our morbid obese patients with a balanced high protein diet for 4 to 6 weeks and at least two weeks preoperative. This help to shrink the large fatty liver minimizing need for liver retractor port. In our series, liver retractor port was necessary in 2 patients, to allow over sewing of the stable line at bleeding points after failure of surgical clips to control bleeding. Nedelcu et al., [11] described a similar three port technique without liver retractor port but with different port sites. Corcelles et al., [12] reported their experience with three port technique but also with different port sites and probability of internal liver retraction by means of suture. Up till now, there is no conclusive data regarding optimal calibrating tube size in creating the gastric sleeve. In our series, stapling was done along a nasogastric calibrating tube of $36 \mathrm{Fr}$ size. The absence of counter traction in our technique prevented creation of tight sleeve. We believe that outcome of surgery depends mainly on perfect surgery technique rather than size of bougie either the stapler was applied loose to the bougie or tight to it and this was reflected on EWL and complication. Abo-Elelaa et al., 2020 concluded that, bougie size does not influence the short-term results of LSG regarding \%EWL, resolution of comorbidities, and incidence of complications [13]. In our series, the mean operative time was $58.46 \pm 18.61$ minutes, which are comparable with the reported results of conventional LSG. Consalvo et al., [14] reported a mean operative time of $43.1 \pm 8.5 \mathrm{~min}$ and $51.5 \pm$ $10.53 \mathrm{~min}$ for their patients subjected to five portsLSG and three port LSG respectively. The relative longer mean operative time in our three port than conventional five port may be attributed to absence of the assistance making mobilization of the greater curvature more difficult and taking longer time. The mean length of hospital stay was $1.25 \pm 0.75$ day, which was short than reported by other $[12,15]$. We could explain shorter hospital stay as a result of two mean reasons: The first is decreased postoperative pain, (as reflected by lower consumption of analgesics), which may be attributed to low insertion of the trocars and absence of epigastric wound. The second is rapid tolerability of oral fluids due to absence of tight sleeve. The mean follow-up was 11.21 \pm 3.07 month (range 6-16 month). Half of our patients $(50 \%)$ had at least 1 year of follow-up. The other half had at least 6 months follow-up. Efficacy is the most important issue of any new procedure technique which must be applied only if the results of the conventional procedure can be duplicated or made better [2]. In our series, all patients achieved a satisfactory mean EWL\% at 6 months (55.69\%). Half of our patients completed 1 year follow-up with EWL\% 69.6\%. The weight loss and comorbidities resolution results are comparable with the reported results of conventional LSG [16]. It is well established that the cosmetic form has a great impact on obese patients going for bariatric surgeries, especially the ladies [17]. In our study, all of our patients were satisfied with their scar appearance especially after 6-month period, (Figs. 11,12).

Conclusions: Three ports LSG is feasible without need for liver retractor port insertion, safe, effective, with minimal $24 \mathrm{~h}$ postoperative pain, short hospital stay and good cosmetic results.

\section{References}

1- DEITEL M., CROSBY R.D. and GAGNER M.: First International Consensus Summit for Sleeve Gastrectomy (SG), New York City, October 25-27, 2007.Obes. Surg., 18: 487-496 2, 2008

2- LAKDAWALA M.A., MUDA N.H., GOEL S. and BHASKER A.: Single-Incision Sleeve Gastrectomy Versus Conventional Laparoscopic Sleeve Gastrectomy-a Randomised Pilot Study Obes. Surg., 21: 1664-70, 2011.

3- ANTARA G.E. and YUSTINA M.: Three-port laparoscopic sleeve gastrectomy: Serial cases report. Intisari Sains Medis, 10 (2): 471-474, 2019.

4- DIMITROKALLIS N., ALEXANDROU A., SCHIZAS D., ANGELOU A., PIKOULIS E. and LIAKAKOS T.: Single-Incision Laparoscopic Sleeve Gastrectomy: Review and a Critical Appraisal, J. Laparoendosc. Adv. Surg. Tech. A, 27 (3): 217-226, 2017.

5- ARRU L., AZAGRA J.S., GOERGEN M., de BLASI V., de MAGISTRIS L. and FACY O.: Three-port laparoscopic sleeve gastrectomy: Feasibility and short outcomes in 25 consecutivessuperobese patients. Cir. Esp., 91: 294-300, 2013.

6- DURANI P., McGROUTHER D.A. and FERGUSON M.W.: The patient scar assessment questionnaire: A reliable and valid patient-reported outcomes measure for linear scars. Plast. Reconstr Surg., 123: 1481-9, 2009.

7- DEITEL M., GAGNER M., ERICKSON A.L. and CROSBY R.D.: Third International Summit: Current status of sleeve gastrectomy. Surg. Obes. Relat. Dis., 7: 749-759, 2011.

8- ROSENTHAL R.J., DIAZ A.A., ARVIDSSON D., BAKER R.S., BASSO N., BELLANGER D., et al.: International Sleeve Gastrectomy Expert Panel Consensus Statement: Best practice guidelines based on experience of $>12,000$ cases. Surg. Obes. Relat. Dis., 8 (1): 8-19, 2012.

9- AKTOKMAKYAN T.V., GUNGOR O. and SUMER A.: Technical details of laparoscopic sleeve gastrectomy. Mini-invasive. Surg., 4: 23, 2020. 
10- RAMOS A.C., BASTOS E.L., RAMOS M.G., BERTIN N.T.S., GALVAO T.D., LUCENA R.T.F., et al.: Technical Aspects of Laparoscopic Sleeve Gastrectomy. Arq Bras Cir. Dig., 28 (1): 65-68, 2015.

11- NEDELCU M., EDDBALI I. and NOEL P.: Three port sleeve gastrectomy: Complete posterior approach Surgery for obesity and related disease, 2: 925-927, 2016.

12- CORCELLES R., BOULES M., FROYLICH D., DAIGLE C.R., HAG A., SCHAUER P.R., et al.: Laparoscopic Three-Port Sleeve Gastrectomy: A Single Institution Case Series. J. Laparoendosc. Adv. Surg. Tech a., 26 (5): 3615,2016 .

13- ABO-ELELAA S.T., SHABANA H., HUSSEINA A.H., ABO-ALIA M.A., ELHADARYA M.K., ELGEIDIEB A.A., et al.: The effect of bougie size on the short-term outcome of laparoscopic sleeve gastrectomy. The Egyptian Journal of Surgery, (39): 1, 2020.
14- CONSALVO V., SALSANO V., SARNO G. and CHAZE I.: Three-Trocar Sleeve Gastrectomyvs Standard FiveTrocar Technique: A Randomized Controlled Trial. Obes. Surg., 27: 3142-3148, 2017.

15- HOYUELA C.: Five-year outcomes of laparoscopic sleeve gastrectomy as a primary procedure for morbid obesity: A prospective study. World J. Gastrointest Surg., 27: 9 (4): 109-117, 2017.

16- EL-ANWAR A. and SHAKER H.: Laparoscopic sleeve gastrectomy for morbid obesity: Does the size of the bougie matter? The Egyptian Journal of Surgery, 35: 3543, 2016.

17- GAILLARD M., TRANCHART H., LAINAS P., FERRETTI S., PERLEMUTER G. and DAGHER I.: Singleport laparoscopic sleeve gastrectomy as a routine procedure in 1000 patients. Surg. Obes. Relat. Dis., 12: 1270-7, 2016.

\title{
وصف تقنية تكميهم المعدة بالمنظار من خلال ثلاث فتحات بالبطن وتيم المعتئيم النتائج الأولية
}

\author{
المقدمة: تعد جراحة تكميم المعدة بالمنظار واحدة من أكثر عمليات انقاص الوزن انتشاراً وبالرغم من ذلك لا توجد تقنية موحدة لإجراء \\ تكميم المعدة بالمنظار \\ الهدف من الدر اسة: كان الهدف من هذه الدراسة هو تقييم مدى إمكانية إجراء تكميم المعدة بالمنظار من خلال ثلاث فتحات صغيرة بالبطن

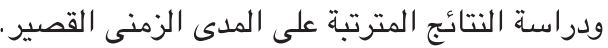

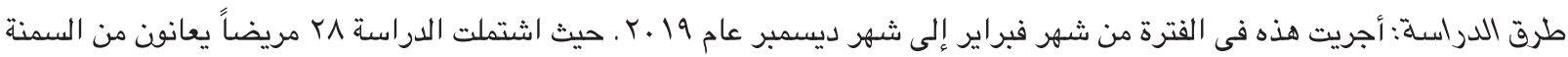

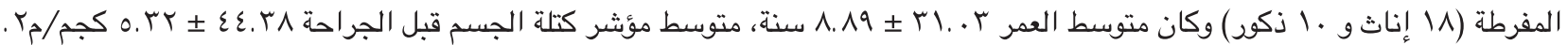 \\ وتم التركيز فى هذه الدراسة على الوصف التفصيل لتقنية تكميم المعدة من خلال ثلاث فتحات، وكذلك تسجيل أى مضاعفات قد حدثت \\ أثناء أو بعد الجراحة ونتائج ما بعد الجراحة المتعلقة بفقدان الوزن الزائد، ومدى التحسن فى الأمراض المصاحبة للسمنة.

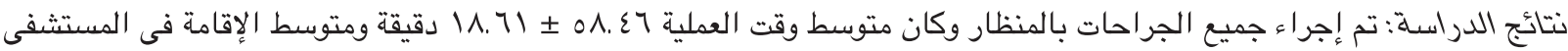

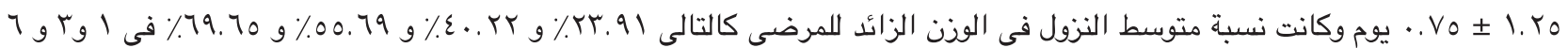

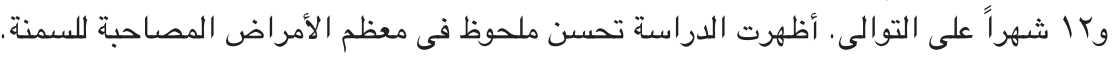 \\ الخلا صةّ: تعتبر تقنية تكميم المعدة بالمنظار من خلال ثلاث فتحات آمنة وفعالة.
}

